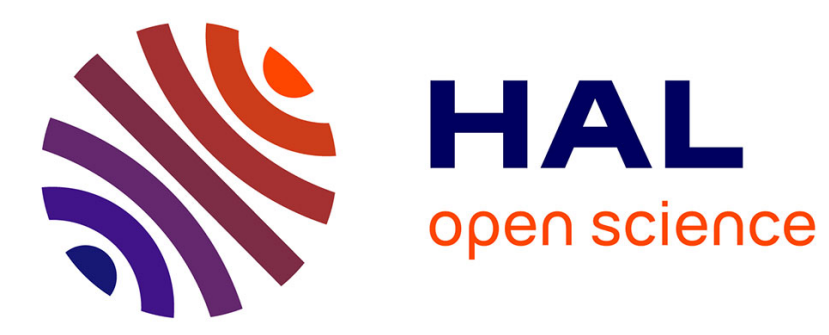

\title{
Impact of a flood event on the biogeochemical behaviour of a mesotrophic alpine lake: Lake Bourget (Savoy)
}

Brigitte Vinçon-Leite, Pierre-Emmanuel Bournet, X. Gayte, D. Fontvieille, Bruno Tassin

\section{- To cite this version:}

Brigitte Vinçon-Leite, Pierre-Emmanuel Bournet, X. Gayte, D. Fontvieille, Bruno Tassin. Impact of a flood event on the biogeochemical behaviour of a mesotrophic alpine lake: Lake Bourget (Savoy). Hydrobiologia, 1998, 373-374 (-), pp.361. hal-00779566

\section{HAL Id: hal-00779566 \\ https://hal-enpc.archives-ouvertes.fr/hal-00779566}

Submitted on 29 Mar 2015

HAL is a multi-disciplinary open access archive for the deposit and dissemination of scientific research documents, whether they are published or not. The documents may come from teaching and research institutions in France or abroad, or from public or private research centers.
L'archive ouverte pluridisciplinaire HAL, est destinée au dépôt et à la diffusion de documents scientifiques de niveau recherche, publiés ou non, émanant des établissements d'enseignement et de recherche français ou étrangers, des laboratoires publics ou privés. 


\title{
Impact of a flood event on the biogeochemical behaviour of a mesotrophic alpine lake: Lake Bourget (Savoy)
}

\author{
B. Vinçon-Leite ${ }^{1}$, P.-E. Bournet ${ }^{1}$, X. Gayte ${ }^{2}$, D. Fontvieille ${ }^{2} \&$ B. Tassin ${ }^{1}$ \\ ${ }^{1}$ CERGRENE - Ecole Nationale des Ponts et Chausshes, Ecole Nationale du Génie Rural des Eaux et des Forêts, \\ F-77455 Marne la Vallée, Cedex 2, France \\ ${ }^{2}$ GRETI (and ESA CNRS n $n^{\circ}$ 5023), Université de Savoie, 73376 Le Bourget du Lac, France
}

Key words: lake, flood, interface, nutrients, bacteria, particles

\begin{abstract}
A flood event which occurred during the onset of thermal stratification and of algal growth (March 1996) was studied in mesotrophic Lake Bourget (France). Both physical and biogeochemical processes occurring during this episode were assessed. The dominant effect was a decrease of nutrient concentrations along the river-lake ecotone. This phenomenon seemed mainly linked to biological factors: stimulation of the spring algal and bacterial growth. After the flood, the algae aggregated with allochthonous particles brought by the river and were rapidly eliminated by sedimentation. The effect of this early spring flood, seemed spatially restricted and rather neutral as regards lake water quality. In the lake region crossed by the river plume, the overall effect after the flood was a decrease of $\mathrm{P}$ available for the phytoplankton. In the open water, the $\mathrm{P}$ concentration was probably not modified by the load supplied by the flood.
\end{abstract}

\section{Introduction}

As pointed out by many authors, lakes exhibit their strongest gradients along the vertical. The order of magnitude of horizontal mixing time scale is the week while the order of magnitude of vertical mixing time scale is the year (Imboden, 1990). Thus, horizontal heterogeneity has been largely neglected and major efforts in limnology are aimed at improving the overall knowledge of lake behaviour by studying the pelagial. The inputs from the watershed are taken into account on large space and time scales but small space and time scale phenomena, including the exchanges of energy, dissolved and particulate species, biotic and abiotic particles in the lake-river interface, are rarely assessed. Nevertheless, during flood events, the interactions between the incoming rivers and the lake may become significant. Field data concerning the physical and chemical processes occurring in the interface region during such periods, and the ensuing biological response, are scarce, the highly random nature of floods preventing the planning of surveys.
Table 1. Mooring trap periods during spring 1996

\begin{tabular}{|c|c|c|}
\hline Dates & Duration & Period $n^{\circ}$ \\
\hline $\operatorname{March} 1^{\text {st }}-14^{\text {th }}$ & 13 days & 1 \\
\hline March $14^{\text {th }}-29^{\text {th }}$ & 15 days & 2 \\
\hline March $29^{\text {th }}-$ April $9^{\text {th }}$ & 11 days & 3 \\
\hline April $9^{\text {th }}-29^{\text {th }}$ & 20 days & 4 \\
\hline
\end{tabular}

Physical impact of a flood is caused by the density current created by the incoming river. Depending on the density difference between lake and river water, a surface overflow, an intermediate depth interflow or a near-bottom underflow is created (Carmack et al., 1979). The intrusion of the river brings about a modification of the lake water circulation. The turbulence associated with this intrusion originates the entrainment of surrounding lake water. Moreover, a flood occurring in spring, during the set-up of the thermal stratification, can affect the depth of the thermocline (Bournet, 1996). Frequently, in small watersheds, 


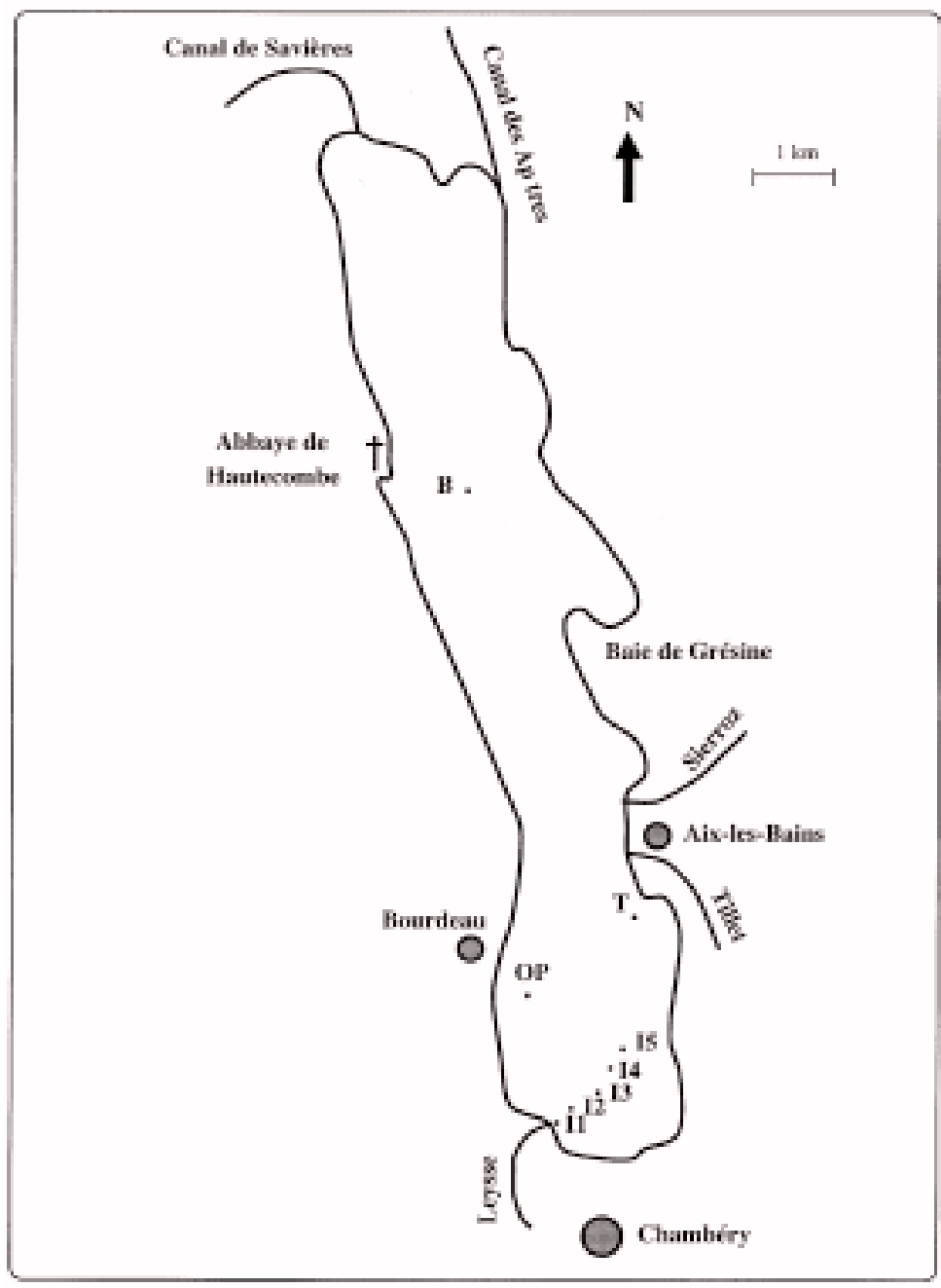

Figure 1. Sampling points during the flood.

flood episodes are associated with meteorological perturbations, especially high wind speeds and cooling of air temperature. Therefore, interactions between the mixing effects driven by meteorological conditions and those caused by the flooding river itself are closely overlapping.

From a biogeochemical point of view, a flood may cause conflicting effects. The suspended solids transported by the turbid inflow into the lake decrease light penetration in the water column and therefore limit algal growth (Tilzer, 1988; Reynolds, 1984). The particulate matter derived from watershed erosion (e.g. small clay particles, metallic oxides) can have a high binding capacity for toxic substances and nutrients (Stabel \& Geiger, 1985; Sigg et al., 1987; Froelich, 1988) and decrease the bioavailability of these species.
This is particularly important for phosphate, which is the limiting nutrient of primary production in many temperate lakes. Soil leaching also increases dissolved organic matter in river water (Boissier \& Fontvieille, 1993). The natural dissolved organic matter (DOM) can present a high complexing capacity and can enhance the adsorption of toxics and nutrients (Zumstein \& Buffle, 1989; Buffle \& Leppard, 1995).

But a flooding river can also introduce to a lake a large amount of nutrients which increases the nutrient stock in the water column (CEMAGREF, 1985; Balland, 1980; Dorioz et al., 1989). Therefore, flood events are suspected to be responsible of a significant amount of annual nutrient loading. In summer, they may contribute to epilimnion nutrient replenishment. Microbial biota is one of the biological component 


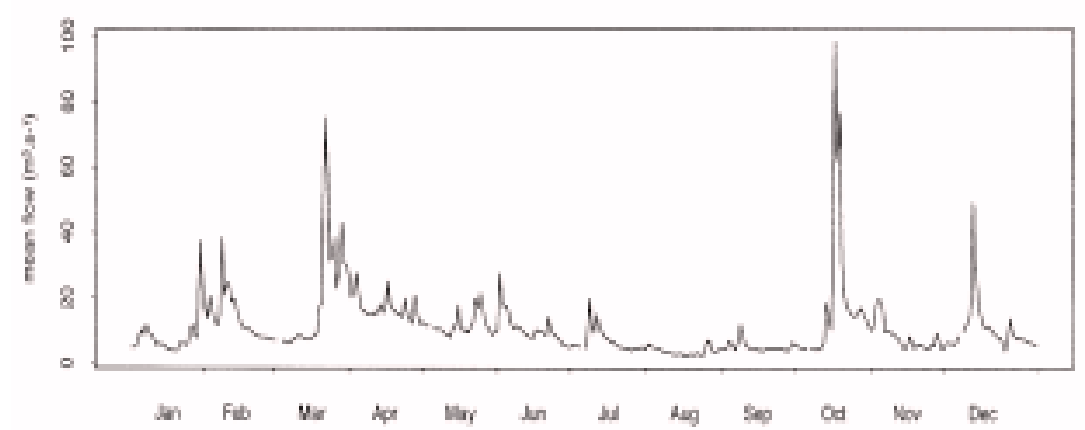

Instantaneous water residences time

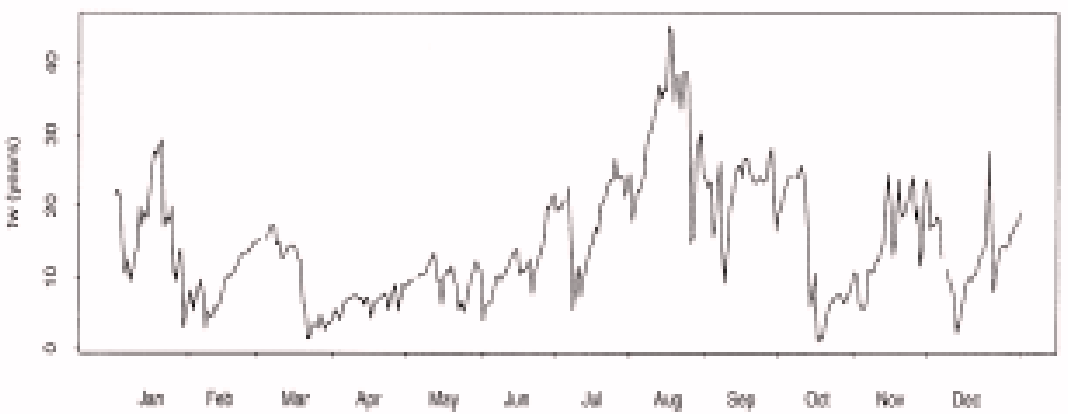

Figure 2. 1988 river Leysse mean flows and instantaneous water residence time.

Table 2. Pre-flood characteristics of river and lake water

\begin{tabular}{lll}
\hline & $\begin{array}{l}\text { River Leysse } \\
\left(9^{\text {th }} \text { February } 1996\right)\end{array}$ & $\begin{array}{l}\text { Lake Bourget } \\
\left(5^{\text {th }} \text { March 1996) }\right.\end{array}$ \\
\hline Total P $\left(\mu \mathrm{g} \mathrm{l}^{-1}\right)$ & 48 & 37 \\
Particulate P $\left(\mu \mathrm{g} \mathrm{l}^{-1}\right)$ & 17 & 4 \\
Total soluble P $\left(\mu \mathrm{g} \mathrm{l}^{-1}\right)$ & 31 & 33 \\
Soluble reactive P $\left(\mu \mathrm{g} \mathrm{l}^{-1}\right)$ & 26 & 26 \\
TSM $\left(\mathrm{mg} \mathrm{l}^{-1}\right)$ & 5.5 & 0.8 \\
BDOC $\left(\mathrm{mg} \mathrm{l}^{-1}\right)$ & 0.54 & 0.28 \\
RDOC $\left(\mathrm{mg} \mathrm{l}^{-1}\right)$ & 2.05 & 2.17 \\
Total number bacteria $\left(\mathrm{cells} \mathrm{ml}^{-1}\right)$ & $5.8810^{+5}$ & $9.17 .10^{+5}$ \\
Bacterial production $\left(\mu \mathrm{gC}^{-1} \mathrm{~h}^{-1}\right)$ & 0.71 & 0.72
\end{tabular}

highly sensitive to such disturbances (Brock, 1966; Fletcher et al., 1987). If little is known about the influence of flood events on phytoplankton behaviour (Elber \& Schanz, 1990), even less is known about the microbial component (Gayte \& Fontvieille, submitted).
Finally, the overall impact of a flood event on a lake is difficult to assess as it depends on four main factors: (1) season, (2) the magnitude of the discharge, (3) the characteristics of the lake and the river water and (4) the suspended matter load. Literature conclusions are often conflicting (Burkholder, 1992). 


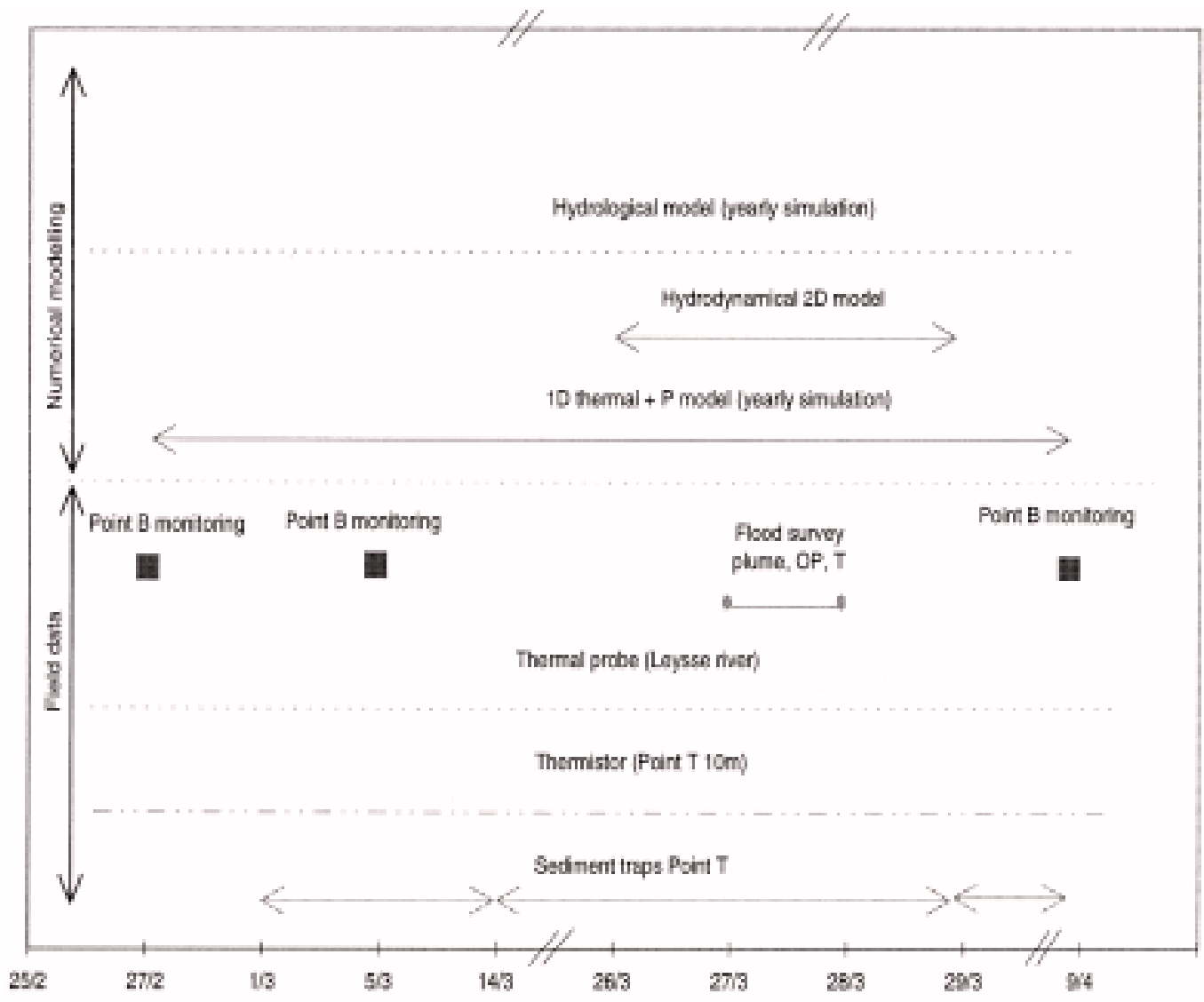

Figure 3. General organization of the flood survey: field measurements and numerical modelling.

Table 3. $\mathrm{Na}^{+}, \mathrm{Cl}^{-}, \mathrm{SO}_{4}^{-2}$ concentrations in river Leysse and lake Bourget surface water

\begin{tabular}{lllc}
\hline & $\mathrm{Na}^{+}\left(\mathrm{mg} \mathrm{l}^{-1}\right)$ & $\mathrm{Cl}^{-}\left(\mathrm{mg} \mathrm{l}^{-1}\right)$ & $\mathrm{SO}_{4}^{-2}\left(\mathrm{mg} \mathrm{l}^{-1}\right)$ \\
\hline Leysse - mean 1996 & 4.7 & 6.5 & 15.3 \\
Leysse (this flood) & 2.8 & 4.15 & 8.5 \\
Lake (surface) - mean 1996 & 4.7 & 6.9 & 14.9 \\
Lake (this flood) & 4.3 & 6.2 & 13.2 \\
\hline
\end{tabular}

A significance of floods in Lake Bourget, mainly on the Phosphorus cycle (P-cycle), has been postulated (Groleau, 1994; Vinçon-Leite et al., 1995). A field survey aimed at monitoring the lake-river interface during a flood was conducted in March 1996. The objective of this paper is to highlight the impact of this flood event in Lake Bourget on both physical and biogeochemical aspects. The physical impact was assessed through river and lake water temperature time series analysis and modelling. The biogeochemical effects were estimated through the characterization of the particles: size distribution, morphological observations with scanning electronic microscope (SEM) and semi-quantitative analysis of their composition (EDX). Bacterial biomass and production were also measured, to better understand DOC and bacterial dynamics in the river plume. 

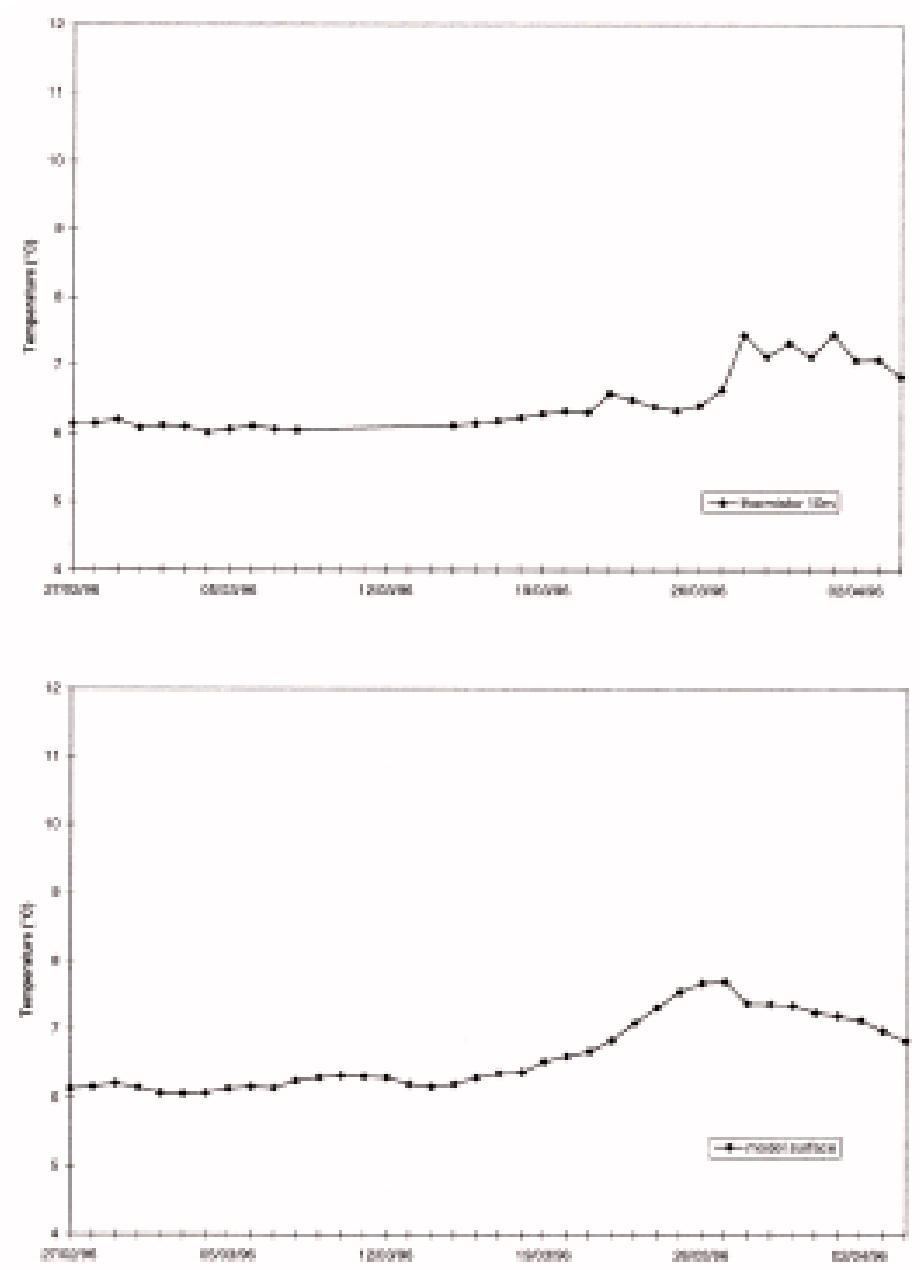

Figure 4. Results of the thermal model (lake surface water) and $10 \mathrm{~m}$ depth thermistor temperature data.

\section{Lake Bourget}

Lake Bourget is a medium sized lake (surface area: $42 \mathrm{~km}^{2}$, maximal depth: $145 \mathrm{~m}$, residence time $\approx 7$ years) located in the French Alps (Figure 1).

The lake watershed area is about $560 \mathrm{~km}^{2}$. The main tributary, river Leysse, has a $320 \mathrm{~km}^{2}$ watershed area and its spring is located at $1200 \mathrm{~m}$ a.s.l.: $75 \%$ of the total water input to Lake Bourget comes from the Leysse. Approximately $30 \%$ of the watershed area has an altitude higher than $1000 \mathrm{~m}$ and is snow covered from December to the end of February. The Leysse discharges upstream of its entrance in Lake Bourget were gauged until 1988. Afterwards the gauging station was disactivated. Since February 1996, a new station, located at the same point, has been installed. Water levels are measured again but the new gauging curves are not yet available, especially for high flows. Therefore, the general hydrological characteristics were established according to the 1980-88 data.

River Leysse mean discharge rate is $8.5 \mathrm{~m}^{3} \mathrm{~s}^{-1}$, and maximum flow measured on the 1980-88 period is c. $100 \mathrm{~m}^{3} \mathrm{~s}^{-1}$. Floods frequently happen in early spring, during snow melting, and in autumn after storm events. They last generally less than a week. Figure 2 shows the daily mean flow of river Leysse in 1988 as an example highlighting the wide range of the instantaneous residence time of water in the lake caused by the variability of daily mean flow. The threshold considered to define a flood is a discharge rate greater than $20 \mathrm{~m}^{3} \mathrm{~s}^{-1}$ (CEMAGREF, 1985). 

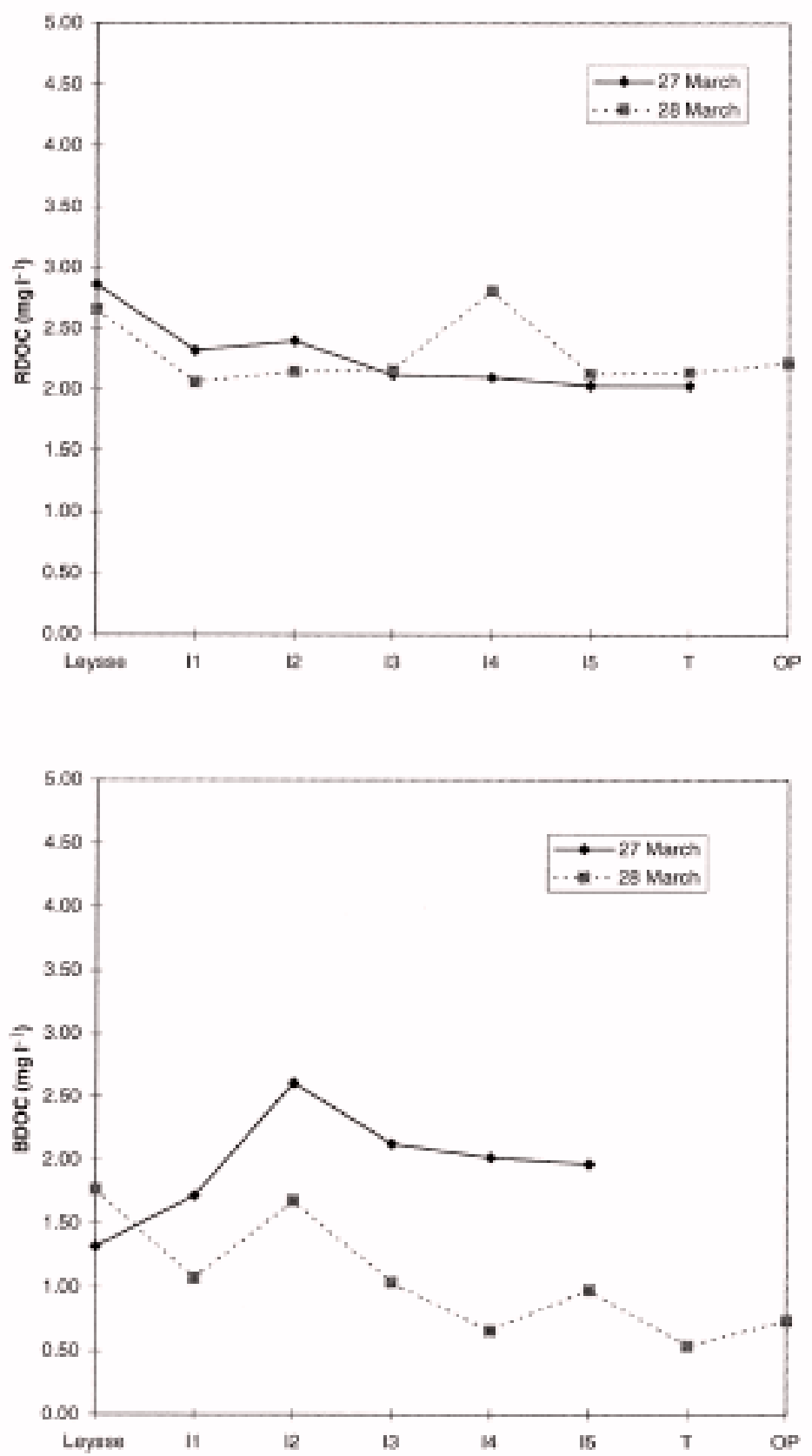

Figure 5. BDOC and RDOC evolution in Lake Bourget on March $27^{\text {th }}-28^{\text {th }} 1996$.

\section{Material and methods}

\section{Methodology}

Following the analysis of data from different points of the lake gathered between 1969 and 1978 (INRA, 1972; CEMAGREF, 1978), it is assumed that Lake
Bourget, on a time scale of days, is horizontally homogeneous and a single point, point $\mathrm{B}$, located at the lake maximum depth (Figure 1) is monthly monitored.

As a flood cannot be forecasted, we can only assess the lake pre-flood conditions through the monthly monitoring. A major difficulty in studying flood events comes from the difference of field sampling scales 
27 March 1996
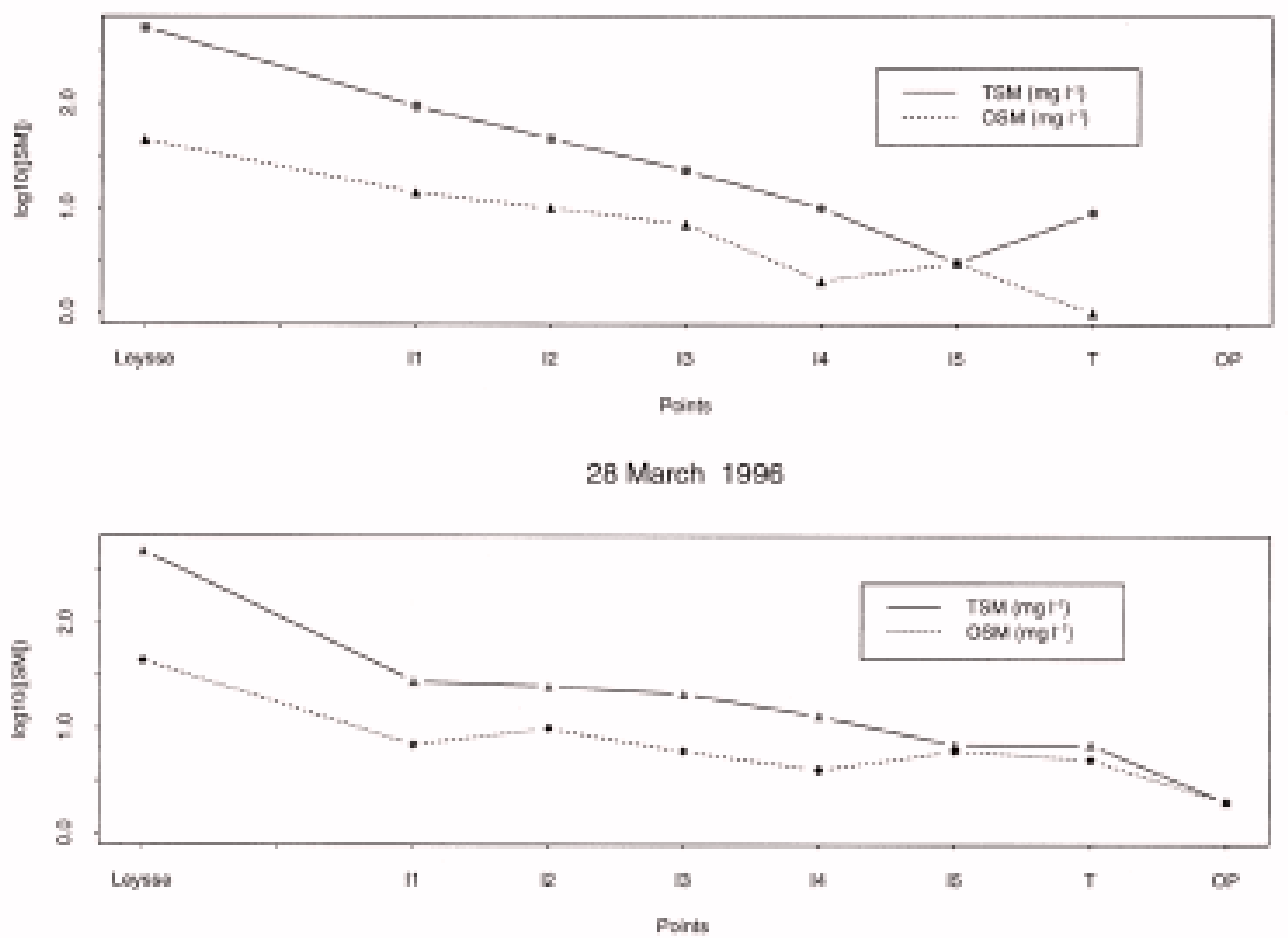

Figure 6. Decimal logarithm of total suspended matter (TSM) and organic suspended matter (OSM) in Lake Bourget on March $27^{\text {th }}-28^{\text {th }} 1996$.

between a regular monitoring and a flood survey. Contrary to a regular monitoring based on large space and time scales and aimed at assessing a seasonal global evolution of the lake, a flood survey needs small space and time scale campaigns to understand the impact of a specific episode on lake seasonal evolution.

Moreover, despite well-defined campaigns, the flood meteorological conditions are generally so unfavourable that the survey may be incomplete. In order to obtain the most complete data set, we followed a methodological approach based on both numerical modelling and field surveys including continuous measurements and punctual sampling.

From a hydrological point of view, the river Leysse discharges were estimated by a hydrological conceptual reservoir model, GR4j, (De Oliveira Nascimento, 1995) whose four parameters were calibrated according to the 1980-88 measured discharges.

Concerning hydrodynamics of river entrance during the flood, a two-dimensional horizontal hydrodynamical model gives the direction, the depth and the extension of the river plume in the lake (Bournet, 1996).
Moreover, a one-dimensional vertical thermal model gives the temperature evolution, the onset of stratification and the occurrence of mixing in the water column. The time and space steps of the model are one day and one meter, respectively. This thermal model is coupled with a model of the phosphorus cycle which includes the processes involving the algal growth (Vinçon-Leite et al., 1995).

Continuous field data are useful to analyze the data collected during a flood event. Therefore, a thermistor chain and sediment traps were moored at point $\mathrm{T}$ (Figure 1). Figure 3 presents a global schema showing the interaction between the field point and continuous measurements and the numerical models.

\section{The flood of March 1996}

The Leysse flood peak was estimated by the hydrological model $G R 4 j$ to approximately $50 \mathrm{~m}^{3} \mathrm{~s}^{-1}$ on March $27^{\text {th }}$. The flood lasted from $26^{\text {th }}$ to $29^{\text {th }}$ March. According to time series of air temperature and rainfall in the watershed, the flood was caused by rain and snow melting in the highlands associated with rain in the lower region of the watershed. This flow rate corre- 


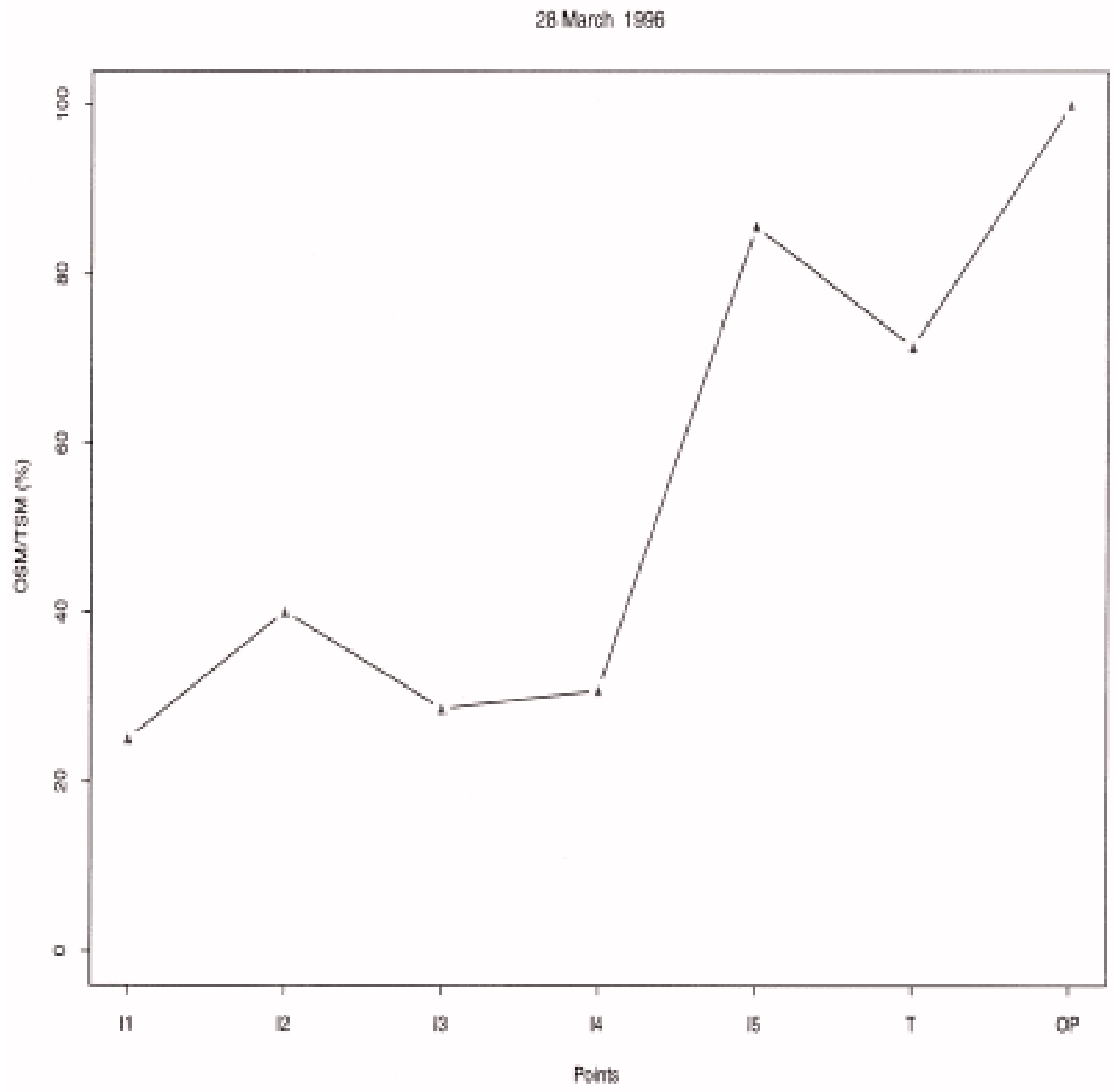

Figure 7. Evolution of the organic suspended matter fraction in the surface lake water on March $28^{\text {th }}$.

sponds approximately to a return period of six months. The impact of even a slight flood is potentially significant as it happens during a sensitive and biologically active period: the set-up of the thermal stratification and the beginning of algal production.

The meteorological data were provided by two Météo-France stations, one located in the highlands of the Leysse watershed (Les Déserts) et the other located at the southern end of the lake (Voglans).

\section{Sampling points}

During the March 1996 flood survey (Figure 1) a daily water sampling was done during two consecutive days $\left(27^{\text {th }}-28^{\text {th }}\right)$ in the Leysse, at point $\mathrm{T}$, and at six additional points (Figure 1).

The river Leysse temperature was continuously measured with a 15 minutes time step by a thermal probe located one $\mathrm{km}$ upstream of the river entrance. Water samples used for the determination of the physical and chemical data were gathered monthly at this same point.

Two reference points are located in the lake: point $\mathrm{B}$, the deepest point $(145 \mathrm{~m})$ in the pelagial area and point $\mathrm{T}$, in the eastern region of the southern basin $(82 \mathrm{~m})$. At point $\mathrm{B}$, a monthly sampling was carried out and at point $\mathrm{T}$, a thermistor chain (Anderaa) (10 thermistors from $10 \mathrm{~m}$ to $51 \mathrm{~m}$ depth) and three sediment traps $(10,30,80 \mathrm{~m})$ were moored. 


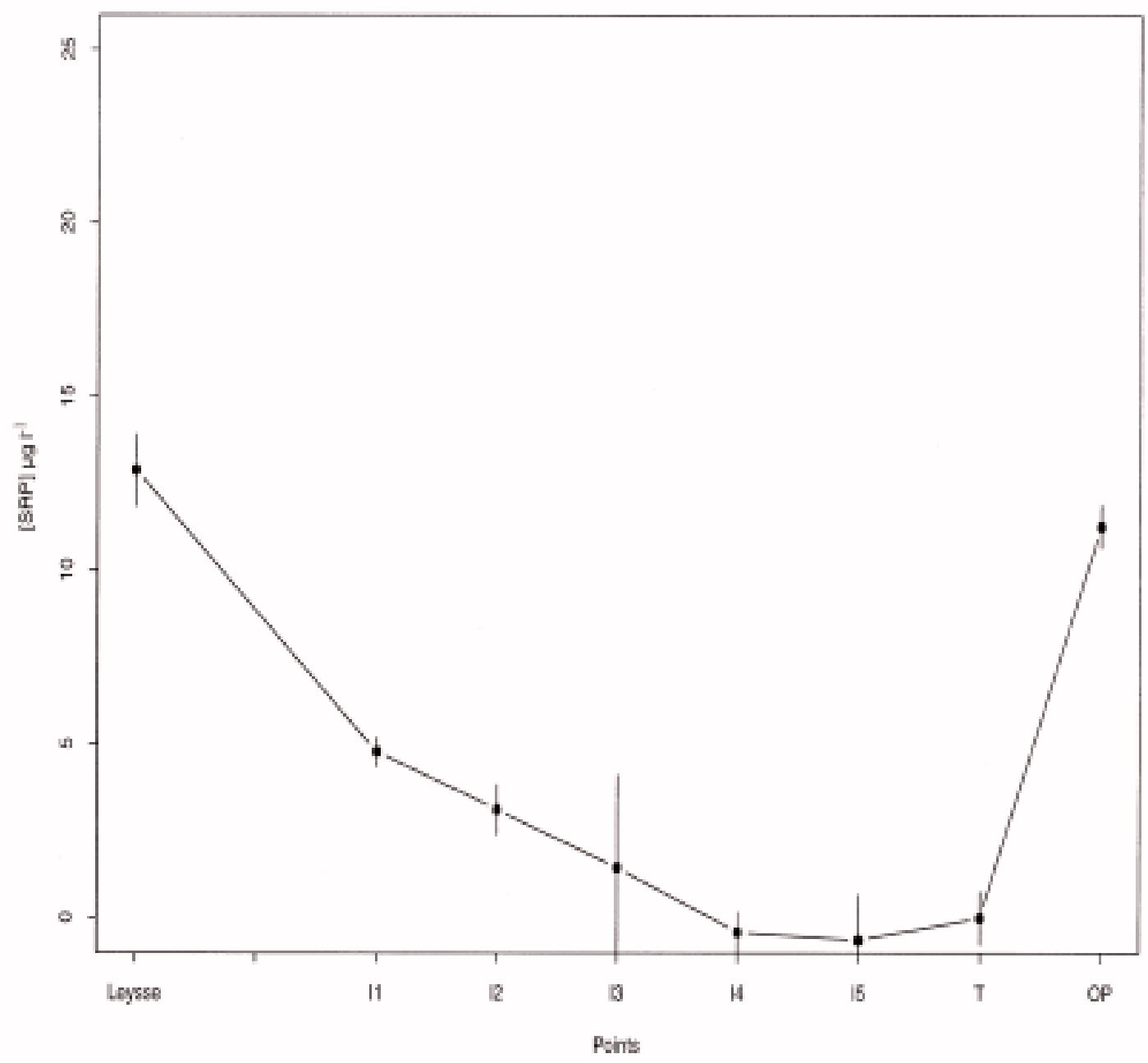

Figure 8. Evolution of the SRP concentration in the surface lake water on March $28^{\text {th }}$. Bars represent the standard deviation.

During the flood survey, five additional points $\left(\mathrm{I}_{1}\right.$, $\left.\mathrm{I}_{2}, \mathrm{I}_{3}, \mathrm{I}_{4}, \mathrm{I}_{5}\right)$ inside the river plume and one point $(O P)$ located outside the plume were sampled. Sampling was done $50 \mathrm{~cm}$ under the water surface as, according to the Leysse and lake relative densities the river was entering the lake as a surface overflow. The location of point $O P$ was determined near the western shoreline according to the hydrodynamical model results (Bournet, 1996) which show that the river plume is deflected towards the east and moves parallel to the shoreline.

\section{Field data}

The same physical, chemical and biological variables were measured in the river and in the lake.

\section{Chemical data}

The major ions $\left(\mathrm{Cl}^{-}, \mathrm{SO}_{4}^{-}, \mathrm{NO}_{3}^{-}, \mathrm{K}^{+}, \mathrm{Ca}^{2}, \mathrm{Na}^{+}\right.$, $\mathrm{Mg}^{2}$ ) were measured by capillary electrophoresis (Waters Quanta 4000). A $100 \mu \mathrm{m} \times 100 \mathrm{~cm}$ capillary (Chromate OFM-OH, $20 \mathrm{kV}, 60 \mathrm{~s}$ ) was used for anion, and a $75 \mu \mathrm{m} \times 60 \mathrm{~cm}$ (UV-CAT2, $20 \mathrm{kV}, 10 \mathrm{~s}$ ) for cation analysis.

The different forms of $\mathrm{P}$ : orthophosphate, total $\mathrm{P}$ in raw water and in filtered water $(0.4 \mu \mathrm{m}$ Cellulose Acetate Nuclepore filter), particulate P on $0.4 \mu \mathrm{m}$ filter were analyzed. Orthophosphate determination was based on the ascorbic acid colorimetric method. The other forms of $\mathrm{P}$ were measured after transformation to orthophosphate by ammonium persulfate digestion (AFNOR, 1986). 

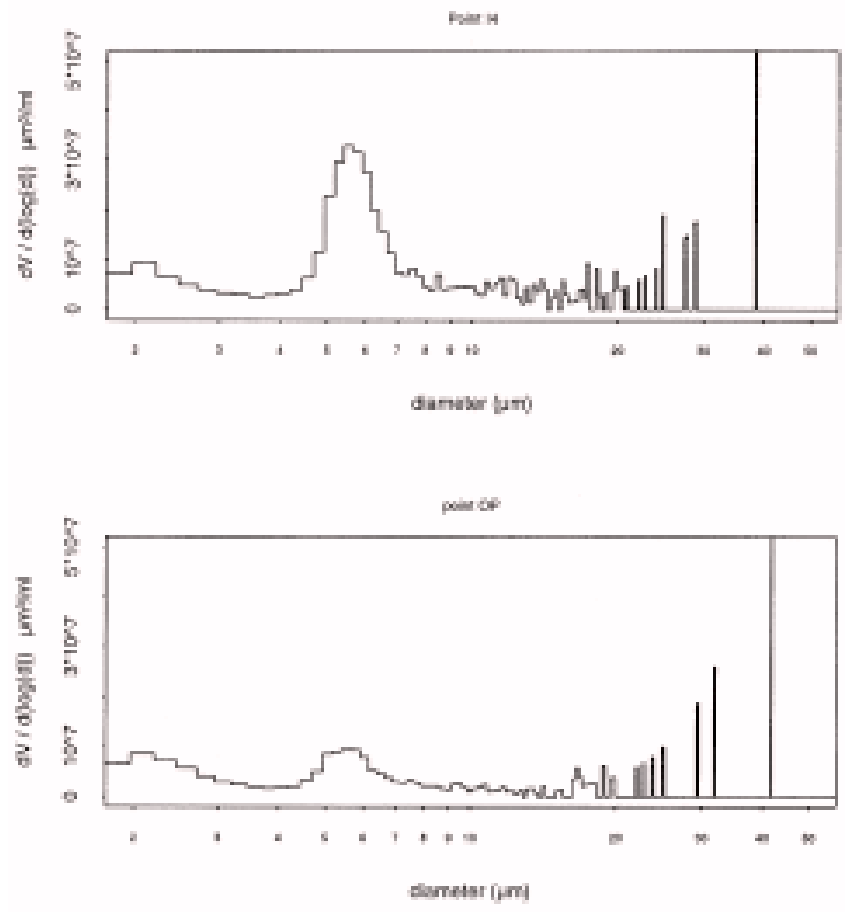

Figure 9. Particle size distribution in Lake Bourget: points $\mathrm{I}_{4}$ and $\mathrm{OP}$ on March $28^{\text {th }}$.

Dissolved organic carbon (DOC) was measured with a Dohrman DC80 'Total Carbon Analyser' based on U.V.-promoted potassium persulfate oxidation after elimination of mineral carbon by orthophosphoric acid. Biodegradable (BDOC) and refractory (RDOC) fractions of the dissolved organic carbon were assessed using the methods of Servais et al. (1987) and Servais et al. (1989). BDOC is that part of the initial DOC concentration which is assimilated by autochthonous bacteria during a short-term incubation (Servais et al., 1987; Boissier \& Fontvieille, 1995). A $0.2 \mu \mathrm{m}$ cellulose acetate membrane (Millipore) was washed three times with $20 \mathrm{ml}$ of organic-C free distilled water and then used to filter $130 \mathrm{ml}$ of the water being investigated. $10 \mathrm{ml}$ were kept for the initial DOC measurement. The remaining $120 \mathrm{ml}$ were then transferred into a $250 \mathrm{ml}$ pre-combusted $\left(550^{\circ} \mathrm{C}, 4 \mathrm{~h}\right)$ glass bottle with an aluminium closure. The bottles were inoculated with a suspension of autochthonous bacteria (removed from the cellulose acetate filter), and incubated in the dark, for 30 and 35 days, at $15{ }^{\circ} \mathrm{C}$. The decrease of DOC concentration is rapid (around 4 or 5 days) and is followed by a stabilization at a constant value until the end of the incubation (Servais et al., 1987; Boissier \& Fontvieille, 1993). The DOC concentration measured at the end of the incubation was considered as biologically refractory (RDOC) and the difference between initial and final values of DOC was considered as the biodegradable fraction (BDOC).

\section{Characterization of particles}

The following analysis were done on particulate matter collected in the river, in the lake and in the sediment traps.

- Total suspended matter (TSM) and organic suspended matter (OSM) were estimated by filtering water on glass fibre filters (Whatman $\mathrm{GF} / \mathrm{F}$ ) previously ignited at $525{ }^{\circ} \mathrm{C}$. The filters were dried at $65^{\circ} \mathrm{C}$ during 48 hours for TSM determination and combusted at $525{ }^{\circ} \mathrm{C}$ for one hour for OSM determination.

- Size distributions were determined by a Coulter Counter using a $100 \mu \mathrm{m}$ orifice which measures particles from 2 to $50 \mu \mathrm{m}$.

- The morphology of the particles was studied with a scanning electronic microscope (ABT55). A semi-quantitative estimation of particle composition was obtained by a EDX micro-analyzer (Kevex). 

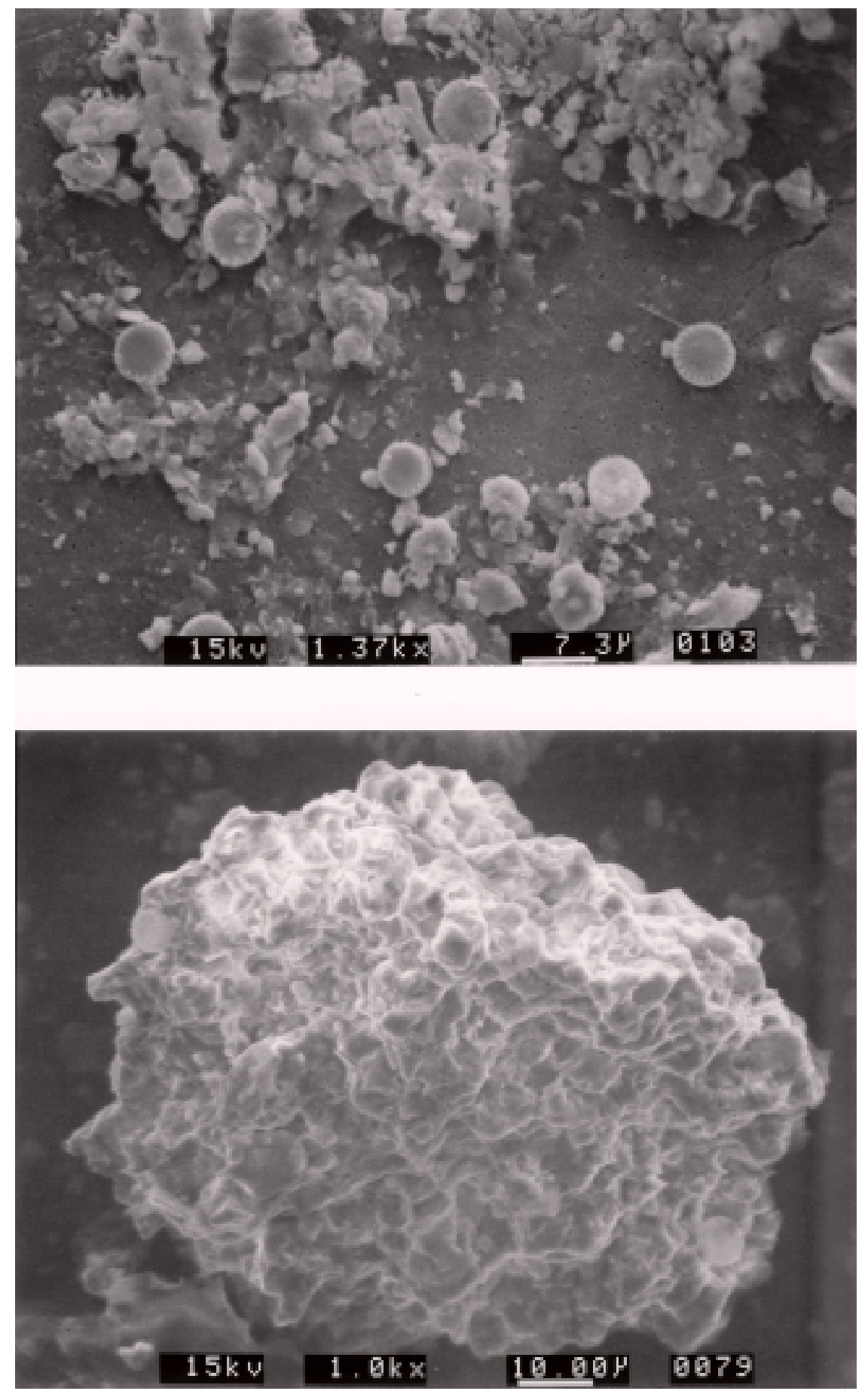

Figure 10. SEM photographs (a) Association of Stephanodiscus and allochthonous mineral particles at point $\mathrm{I}_{1}$ on March $27^{\text {th }}$. (b) View of some Stephanodiscus cells attached on a large alumino-silicate particle. 
27 March 1996

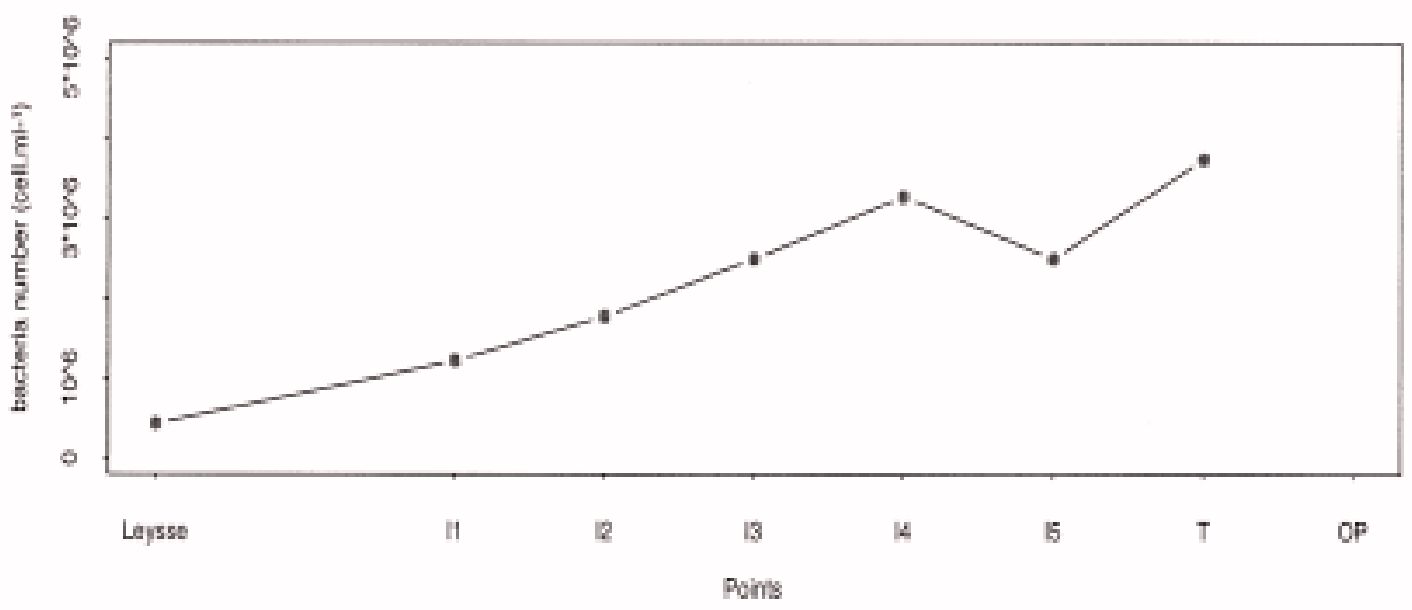

28 March 1996

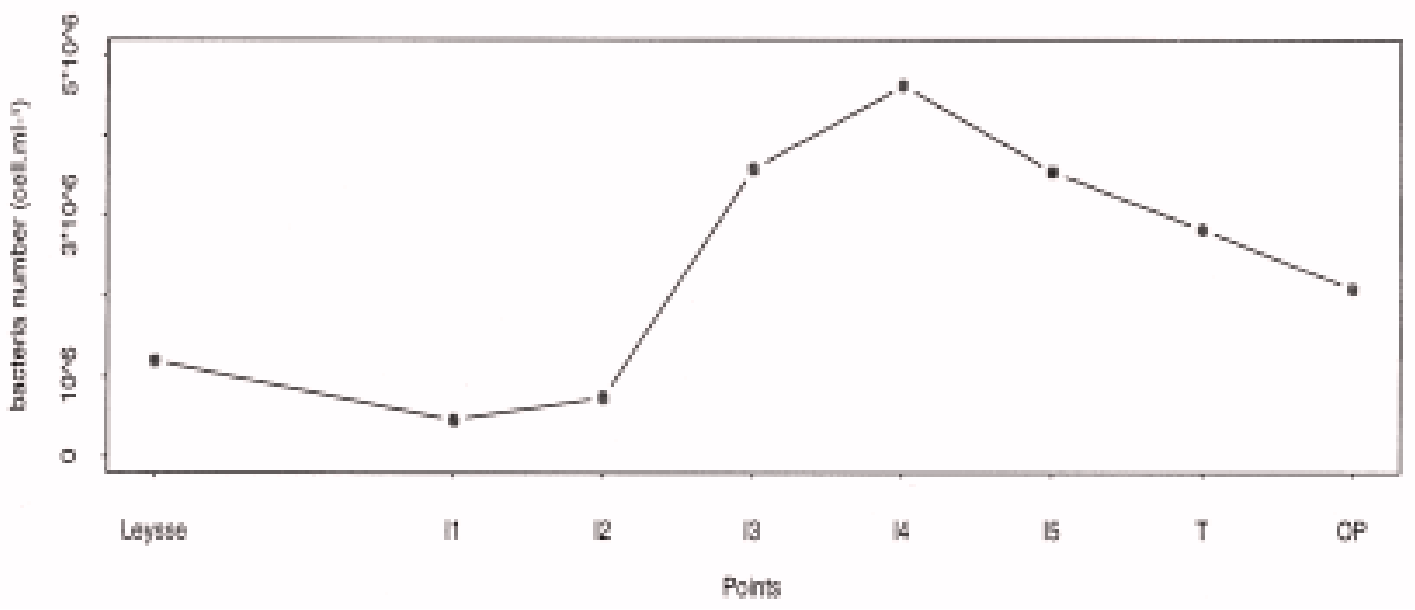

Figure 11. Bacterial biomass in Lake Bourget on March $27^{\text {th }}-28^{\text {th }} 1996$.

\section{Trap sediments}

The particulate matter was collected in the sediment traps during approximately two week periods (Table 1). In addition to the characterization of the particles following the methods presented in Section 3.4.2, organic carbon, organic nitrogen, $\mathrm{Ca}, \mathrm{Mg}, \mathrm{K}, \mathrm{Na}$, $\mathrm{Fe}, \mathrm{Mn}, \mathrm{P}, \mathrm{Al}, \mathrm{Si}$, were analyzed at the Laboratoire d'analyse des sols (INRA ${ }^{1}$ Arras), according to (AFNOR, 1996). Organic carbon and nitrogen were measured by elemental analysis (Carlo Erba CHN analyzer). Total $\mathrm{Ca}, \mathrm{Mg}, \mathrm{K}, \mathrm{Na}, \mathrm{Fe}, \mathrm{Mn}, \mathrm{P}$, and $\mathrm{Al}$ were analyzed after $\mathrm{HF} / \mathrm{HClO} 4$ digestion. $\mathrm{P}$ was determined

\footnotetext{
1 INRA: French National Institute for Agronomical Research
}

by a colorimetric method. $\mathrm{Ca}, \mathrm{Fe}, \mathrm{Mg}$ and $\mathrm{Mn}$ were determined by flame atomic absorption spectrometry. $\mathrm{K}$ and $\mathrm{Na}$ were analyzed by flame atomic emission spectrometry. Al was analyzed by plasma emission spectroscopy and Si by X fluorescence. The chlorophyll $a$ composition was determined by a spectrophotometric method after acetone pigment extraction (AFNOR, 1986).

\section{Bacterial data}

Bacterial counts were performed using epifluorescence microscopy. The total number of bacteria was estimated after DAPI staining (Porter \& Feig, 1980; Fry, 1988). The incorporation of 3H-methyl thymi- 
27 March 1996

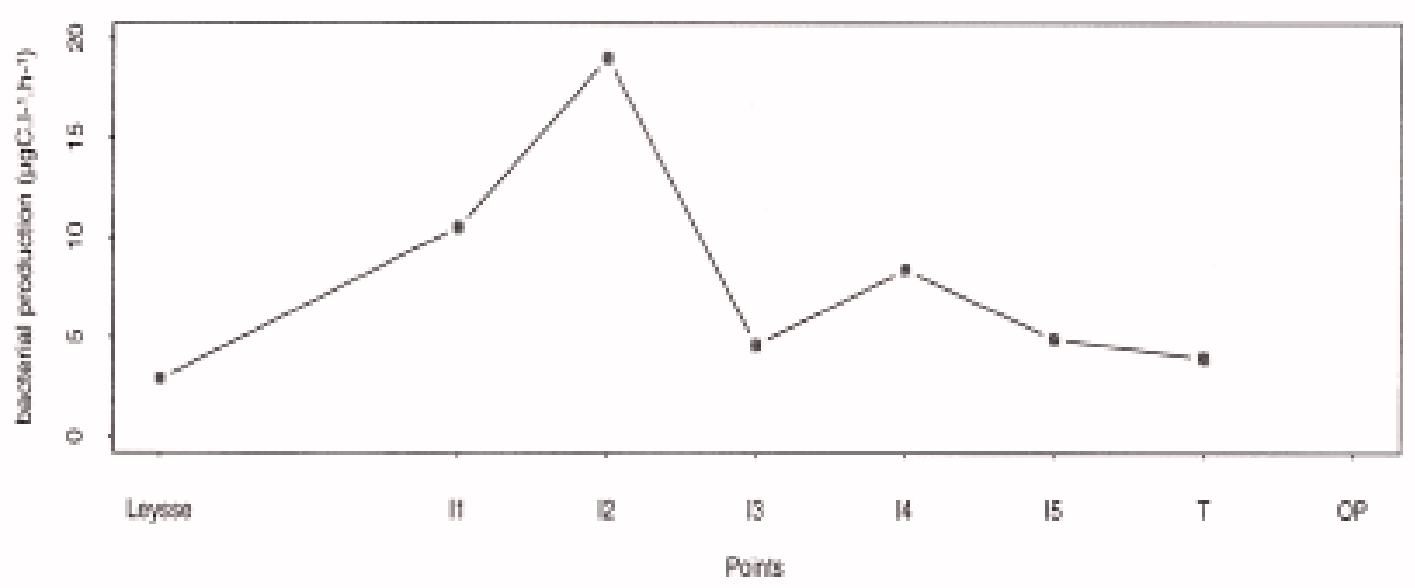

28 March 1996

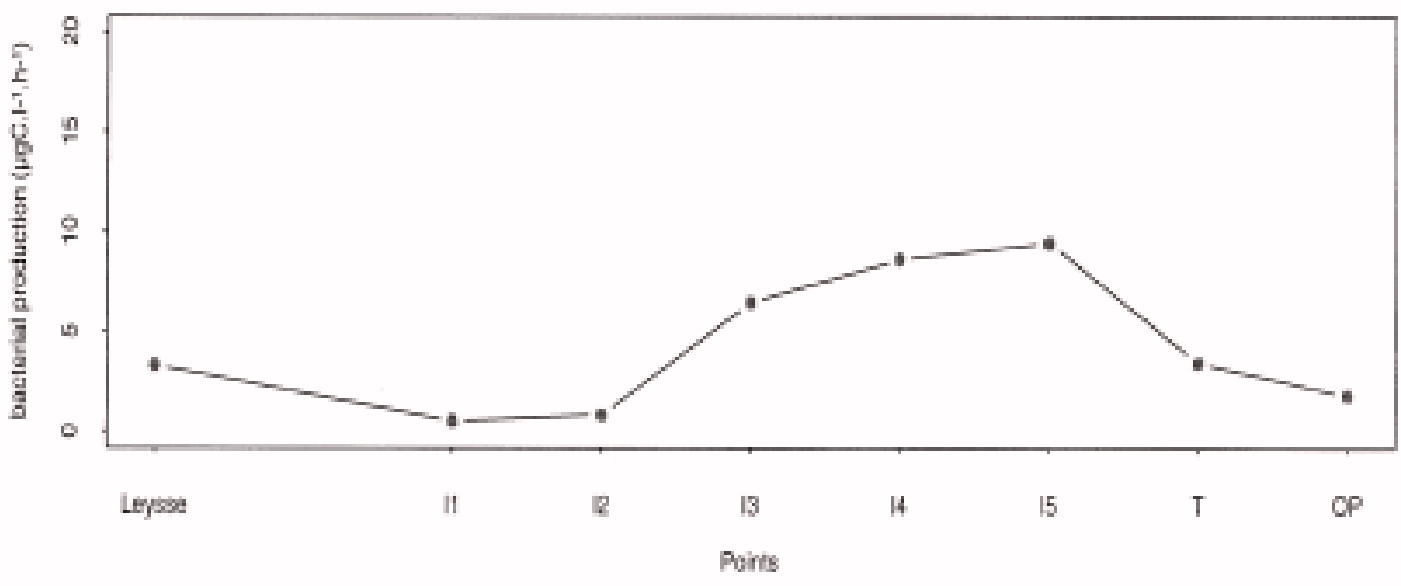

Figure 12. Bacterial production in Lake Bourget on March $27^{\text {th }}-28^{\text {th }} 1996$.

dine into ice-cold trichloroacetic acid (TCA) insoluble material was used to estimate heterotrophic bacterioplankton production (Furhman et al., 1982).

\section{Results}

Pre-flood conditions: the limnological context

In order to characterize the context before the flood, physical, chemical and biological conditions in Leysse river and in lake Bourget are presented.

\section{The Leysse river}

The time series of the Leysse and the lake temperature for the days preceding the flood indicate that river temperature was close to lake surface temperature. These data and the hydrodynamical model results agree in indicating that on the peak flow day (March $27^{\text {th }}$ ), the river entered into the lake, spreading on the lake surface. According to the hydrodynamical model, the plume reached point $\mathrm{I}_{5}(\approx 1.5 \mathrm{~km}$ from the river mouth) after few hours and reached point $T(\approx 4 \mathrm{~km})$ in one day. Leysse pre-flood concentrations are available on February $9^{\text {th }}$ because of a sampling problem on March $5^{\text {th }}$. Chemical and bacterial data are presented in Table 2. 


\section{Lake Bourget}

Data collected on March $5^{\text {th }} 1996$ at the pelagial point B (see Figure 1), as part of the regular monthly monitoring were used to estimate lake conditions before the flood. This campaign took place during a dry weather period when the Leysse discharge was estimated by the hydrological model to approximately $4 \mathrm{~m}^{3} \mathrm{~s}^{-1}$. The lake was considered horizontally homogeneous before the flood and point B conditions were extrapolated to the southern basin of the lake. At point B, on March $5^{\text {th }}$, the water column was vertically homogeneous with a mean temperature of $6{ }^{\circ} \mathrm{C}$ and a mean oxygen concentration of $10.2 \mathrm{mg}^{-1}$. Lake chemical and bacterial data are shown in Table 2. The water transparency (secchi depth: $15 \mathrm{~m}$ ) indicates that algal growth had not yet begun. Neither the SEM observations of suspended matter nor its granulometric distribution did show any specific particle population.

Information about algal growth was obtained from the suspended matter collected in the sediment traps. A tenuous $6 \mu \mathrm{m}$ peak appears in the particles collected by the $10 \mathrm{~m}$ trap, suspended in the well mixed upper layer during 14-29 March, indicating that algal growth might have just begun during the second half of March. The chlorophyll flux estimated from the data of this sediment trap is very small in March $(\approx 2 \mathrm{mg}$ $\mathrm{m}^{-2}$ day $^{-1}$ ). It increased to $17 \mathrm{mg} \mathrm{m}^{-2}$ day $^{-1}$ in the following period (March $29^{\text {th }}-$ April $9^{\text {th }}$ ).

Lake temperature data at $10 \mathrm{~m}$ depth are available from the chain first thermistor. In order to estimate the lake surface temperature, a one-dimensional vertical thermal model (Vinçon-Leite et al., 1995) was used. The results show a slight temperature increase in lake surface water, approximately $1.4 \circ \mathrm{C}$, from $14^{\text {th }}$ to $27^{\text {th }}$ March. The thermistor data show also a light temperature increase of $0.2{ }^{\circ} \mathrm{C}$ at $10 \mathrm{~m}$ depth (Figure 4). Therefore, over the period between the $5^{\text {th }}$ of March and the flood, there probably was only a slight surface thermal stratification. Finally, during the period preceding the flood, algal production had possibly begun but probably slowly.

\section{Physical-chemical variables evolution during the flood}

\section{Dissolved minerals and organic matter}

Among minerals, $\mathrm{Cl}^{-}, \mathrm{SO}_{4}^{-}$and $\mathrm{Na}^{+}$presented the highest changes along the river-lake ecotone. During dry weather, river and lake concentrations were close, reflecting the biogeochemical background of the watershed. During the flood, river concentrations de- creased by about $40 \%$ of dry weather concentrations (Table 3) indicating a classic dilution effect (Meybeck, 1985). Flood lake concentrations remained close to mean 1996 concentrations.

RDOC displayed a near constant concentration both in time and space, although its concentration was higher in the river than in the lake (Figure 5). On the contrary, obvious BDOC concentration changes occurred on a daily time scale: consumption of $1 \mathrm{mg} \mathrm{l}^{-1}$ between the two days of the study in the plume region (Figure 5).

\section{Particulate matter}

Total suspended matter (TSM) and organic suspended matter (OSM) increased significantly during the flood (Figure 6). The fraction of organic matter in total suspended matter increased from the mouth of the river to the offshore points. Outside the river plume, on March $28^{\text {th }}$ the suspended matter concentration was significatively lower than at the end of the plume region $\left([\mathrm{TSM}]=7 \mathrm{mg}^{-1}\right.$ at point $\mathrm{T}$ and $[\mathrm{TSM}]=2 \mathrm{mg}$ $\mathrm{I}^{-1}$ at point $\left.\mathrm{OP}\right)$. Moreover at point OP, nearly $100 \%$ of the suspended matter was organic (Figure 7).

Particulate $\mathrm{P}(\mathrm{PP})$ increased during the flood, but total P (TP) increased only lightly. Total soluble P (TSP) and soluble reactive P (SRP) both decreased significantly. The decrease of SRP within the plume was clearly higher than at the outside-plume point OP (Figure 8).

\section{Evolution of the particles during the flood}

On the $27^{\text {th }}$ and $28^{\text {th }}$, the number of particles strongly increased in the river and in the lake. The size distribution of the river particles was uniform but lake particle distribution was unimodal, with a clear $6 \mu \mathrm{m}$ peak (Figure 9). This peak appeared at all points located inside the plume on March $27^{\text {th }}$. It was higher near the entrance of the river. SEM observations identified this population of particles as Stephanodiscus, a small centric diatom. On the $28^{\text {th }}$, the $6 \mu \mathrm{m}$ particle population disappeared at points $I_{1}$ and $I_{2}$. It remained present at the offshore points but the number of particles decreased (Leroy, 1996). At point OP, a clearly smaller peak was observed (Figure 9). The SEM observations (Figure 10) also indicated an agglomeration of diatoms and coarse allochthonous mineral particles, which increased in settling rate and may explain the disappearance of the $6 \mu \mathrm{m}$ particles near the river entrance on March $28^{\text {th }}$. 


\section{Bacterial dynamics}

During both days of the survey, cell numbers were higher in the lake than in the river (Figure 11). On March $27^{\text {th }}$ a gradient established in the mixing area between river and lake water. However, on March $28^{\text {th }}$, bacterial concentration displayed a maximum in this area together with the maximum of the bacterial production. At that time, bacterial production was half flat on March $27^{\text {th }}$ (Figure 12).

\section{Discussion}

An overall decrease of nutrients (SRP and BDOC) was observed during this flood along the river-lake ecotone. This phenomenon seems to be due to biological, physical and meteorological factors.

\section{Biological factors}

The most significant influence of the flood on the lake seemed a stimulation of the biological activity in the region affected by the river plume. As seen in Paragraph 4.1.2, algal growth had only just begun when the flood occurred. The larger decrease of SRP concentration inside than outside the plume may be due to phosphate uptake by Stephanodiscus. According to Burkholder (1992), increasing suspended particle concentration enhances phosphate uptake by algae as a survival mechanism under episodic sediment loading. The granulometric data (Figure 9) and SEM observations corroborate this interpretation: the cell number of the dominant algae, Stephanodiscus, was much higher inside the plume than outside. Moreover, the P-cycle model was used to estimate the algal SRP uptake in the lake surface water during the 5-28 March period. No specific calibration of the model parameter set was performed for this simulation. The parameter values used were those obtained formerly according to the previous year field data (Vinçon-Leite et al., 1995). At $28^{\text {th }}$ March, the model SRP concentration is $10 \mu \mathrm{gP}$ $1^{-1}$, close to the concentration measured at point OP outside the river plume. This indicates that the model, which does not take into account the specific processes occurring during the flood, is not able to represent the SRP exhaustion by the stimulated algal activity observed in the plume region. In compensation, outside the plume, the model algal SRP uptake correctly explains the SRP decrease.

The microbial activity (pelagial bacteria) might also have contributed to the SRP concentration de- crease in the plume where the highest values of bacterial production were found. Bacterial uptake of phosphate may be high enough to compete with algal consumption (Rhee, 1972; Vadstein et al., 1988).

The importance of BDOC consumption observed in the plume which was similar to that found in others fields (Servais et al. 1987; Boissier \& Fontvieille, 1993; Gayte \& Fontvieille, submitted) may also be explained by bacterial production if we apply bacterial growth yields obtained on natural DOC: $25 \%$ (Hannish et al., 1996).

\section{Influence of allochthonous particles}

Additional scavenging of phosphate by mineral clay particles could explain the large decrease of SRP in the plume. Indeed, mineral suspended matter concentration was higher inside than outside the plume and a fraction of phosphate could be adsorbed to mineral suspended matter. Phosphate partitioning between suspended sediment and phytoplankton is difficult to estimate. Nevertheless it can be assumed that the SRP pattern was mainly caused by biological uptake because mineral suspended matter is generally unable to adsorb SRP under $10 \mu \mathrm{g} \mathrm{l}^{-1}$ (Froelich, 1988).

Soluble unreactive P (SUP) did not increase, therefore phosphate adsorption by humic colloidal matter originated from the soil watershed leaching and transported into the lake by the river was probably negligible.

Another significant process was the aggregation of diatom cells to mineral particles (Figure 10b). This association increased the settling rate of the algae, which were rapidly eliminated by sedimentation wherever suspended sediment concentration was high.

\section{Post flood conditions: Influence of meteorological perturbation}

A flood episode is frequently accompanied by strong wind and air cooling. Meteorological conditions may cause a mixing of the water column which dilutes the biogeochemical impact of the flood. SEM observations of the particulate matter collected in the traps after the flood showed that Stephanodiscus cells rapidly reached the bottom of the water column. Stephanodiscus was abundant in the $10 \mathrm{~m}, 30 \mathrm{~m}$ and $80 \mathrm{~m}$ traps moored after the flood, during period 3 (March $29^{\text {th }}-$ April $9^{\text {th }}$, see Table 1) and was absent during the previous period (March $14^{\text {th }}-29^{\text {th }}$ ). Settling rate computed according to Stokes' equation is approximately $1 \mathrm{~m} \mathrm{day}^{-1}$, a value much lower than that necessary for 
Stephanodiscus to reach the bottom of the lake within 2 weeks by sinking only. If we assume that algae are transported downwards in association with larger and denser mineral particles (Figure 10b), an apparent settling rate of $20 \mathrm{~m} \mathrm{day}^{-1}$ can be estimated on the basis of size. This value may allow the algae to reach the $80 \mathrm{~m}$ traps. The hypothesis of vertical mixing of the lake after the flood can also explain the distribution of Stephanodiscus over the whole water column. The results of the unidimensional vertical thermal model corroborate this hypothesis. A complete mixing occurred at the beginning of April. Therefore, the algal population whose growth was stimulated by the flood and whose settling was increased by aggregation with mineral particles was transported still faster towards the lake bottom by water column mixing.

\section{Conclusion}

A flood event during the setup of thermal stratification (March 1996) was studied in mesotrophic Lake Bourget. The dominant process was the decrease of nutrient concentrations along the river-lake ecotone. This phenomenon seems due to physical and biological factors acting together. The flood stimulated both algal and bacterial growth. The algal growth production had probably begun some days before the flood. This would explain that the flood stimulation lasted a very short time (less than $24 \mathrm{hrs)}$ leading to a fast consumption of SRP and of BDOC. But the role of the river plume was significant because biological activity was more intense in the plume than outside the panache. The decrease of SRP concentration to such a low level could hardly be explained by adsorption on clay particles or humic matter.

Another key process was the association of algal cells with allochthonous mineral particles, which resulted in an increased settling rate. After the flood, sedimentation was also accelerated by a mixing of the water column which distributed the particles over the whole water column.

The overall effect of this flood was to depress the available phosphate for the phytoplankton in the region crossed by the river plume. The high $\mathrm{P}$ uptake during the flood exhausted the epilimnetic phosphate. The large diatom population which developed was then rapidly eliminated by sedimentation. Thus, the $\mathrm{P}$ load brought into the lake by the river during this flood did probably not contribute to an increase of the open water $\mathrm{P}$ concentration.
This study demonstrated the importance of physical and biological factors acting together, in reducing nutrient loads coming from the watershed to lakes during flood events, even during a rather small flood. It indicates that management changes in the watershed which would alter the hydrological cycle and the suspended matter loading to the lake could have a significant impact on lake water quality. The study of these particular flood periods seems important to identify the processes which control lake dynamics and which may be different according to season, river discharge and lake physical and chemical conditions.

\section{Acknowledgements}

This work was conducted in collaboration between CERGRENE (ENPC-ENGREF) and GRETI (Université de Savoie). It was supported by the French Ministry of Agriculture, the Agence de l'Eau RhôneMéditerranée-Corse and the lakeside intercommunal councils (SILB and SIAC). We thank C. Leroy and S. Halbout for their contribution in the laboratory and the field surveys. We are grateful to the Cellule technique du lac du Bourget and particularly Gérard Paolini for his essential contribution to the field surveys. We are grateful to the two referees whose valuable comments have largely improved this paper.

\section{References}

AFNOR, 1986. Eaux - Méthodes d'essai. AFNOR, Tour Europe, Paris.

AFNOR, 1996. Recueil de normes - Qualité des sols. AFNOR, Tour Europe, Paris, 3ème édition.

Balland, P., 1980. La lutte contre l'eutrophisation des lacs Méthodologies de quantification des flux superficiels. Technical report, ENGREF, Département Formation Continue.

Boissier, J.-M. \& D. Fontvieille, 1993. Biodegradable dissolved organic carbon in seepage waters from two forest soils. Soil Biol. Biochem. 25: 1257-1261.

Boissier, J.-M. \& D. Fontvieille, 1995. Biological characteristics of forest soils and seepage waters during simulated rainfalls of high intensity. Soil Biol. Biochem. 27: 139-145.

Bournet, P.-E., 1996. Contribution à l'étude hydrodynamique et thermique du lac du Bourget - Courants de densité et ondes internes. PhD thesis, Ecole Nationale du Génie Rural, des Eaux et des Forêts.

Brock, T., 1966. Principles of microbial ecology. Prentice-Hall inc., Englewood New-Jersey, 306 pp.

Buffle, J. \& G. Leppard, 1995. Characterization of aquatic colloids and macromolecules. 1. Structure and behavior of colloidal material. Envir. Sci. Techn. 29: 2169-2175. 
Burkholder, J. M., 1992. Phytoplankton and episodic suspended sediment loading: phosphate partitioning and mechanisms for survival. Limnol. Oceanogr. 37: 974-988.

Carmack, E. C., C. H. Pharo \& R. J. Daley, 1979. Importance of lake-river interaction on seasonal patterns in the general circulation of Kamloops Lake, British Columbia. Limnol. Oceanogr. 21: 634-644

CEMAGREF, 1978. Le lac du Bourget - Bilan des observations menées en 1975-76-77. Technical report, Centre National du Machinisme Agricole, du Génie Rural, des Eaux et des Forêts, Lyon, France.

CEMAGREF, 1985. Le lac du Bourget - Etude 1983. Technical report, CEMAGREF - DQEPP.

De Oliveira Nascimento, N., 1995. Appréciation à l'aide d'un modèle empirique des effets d'actions anthropiques sur la relation Pluie-Débit à l'échelle d'un bassin versant. $\mathrm{PhD}$ thesis, Ecole Nationale des Ponts et Chaussées.

Dorioz, J.-M., E. Pilleboue \& A. Ferhi, 1989. Dynamique du phosphore dans les bassins versants: Importance des phénomènes de rétention dans les sédiments. Wat. Res. 23: 147-158.

Elber, F. \& F. Schanz, 1990. The influence of a flood event on phytoplankton succession. Aquat. Sci. 52/4: 330-344.

Fletcher, M., T. Gray \& J. Jones, 1987. Ecology of microbial communities. Cambridge University Press, $440 \mathrm{pp}$.

Froelich, P. N., 1988. Kinetic control of dissolved phosphate in naturals rivers and estuaries: a primer on the phosphate buffer mechanism. Limnol. Oceanogr. 33: 649-668.

Fry, J., 1988. Methods in aquatic bacteriology. In B. Austin (ed.), Determination of biomass, John Wiley \& Sons Ltd., New York, USA: $27-72$

Furhman, J., J. Ammerman \& F. Azam, 1982. Thymidine incorporation as a measure of heterotrophic bacterioplankton production in marine surface waters: evaluation and field results. Mar. Biol. 66: $109-120$.

Groleau, A., 1994. Contribution à l'étude de l'influence des crues sur le cycle du phosphore dans le lac du Bourget. DEA Sciences et Techniques de l'Environnement. Ecole Nationale des Ponts et Chaussées, Ecole Nationale du Génie Rural, des Eaux et des Forêts, Paris, France.

Hannish, K., B. Schweitzer \& M. Simon, 1996. Use of dissolved carbohydrates by planktonic bacteria in a mesotrophic lake. Microb. Ecol. 31
Imboden, D. M., 1990. Large Lakes: Ecological structure and function. In M. M. Tilzer \& C. Serruya (eds), Mixing and Transport in Lakes: Mechanisms and Ecological Relevance. Springer-Verlag: 47-80.

INRA, 1972. Suivi du lac du Bourget. Technical report, Institut national de la Recherche Agronomique, Thonon-les-Bains, France.

Leroy, C., 1996. Caractérisation et évolution dans le temps des particules dans le lac du Bourget. DEA Sciences et Techniques de l'Environnement. Ecole Nationale des Ponts et Chaussées, Ecole Nationale du Génie Rural, des Eaux et des Forêts, Paris, France.

Meybeck, M., 1985. Variabilité dans le temps de la composition chimique des rivières et de leurs transports en solution et en suspension. Rev. Sci. de l'Eau 4: 93-121.

Porter, K. \& Y. Feig, 1980. Use of DAPI for identifying and couting aquatic microflora. Limnol. Oceanogr. 25: 943-948.

Reynolds, C. S., 1984. The Ecology of Freshwater Phytoplankton. Cambridge University Press, Cambridge.

Rhee, G.-Y., 1972. Competition between an alga and an aquatic bacterium for phosphate. Limnol. Oceanogr. 17: 505-514.

Servais, P., A. Anzyl \& C. Ventresque, 1989. A simple method for the determination of the biodegradable dissolved organic carbon in waters. Appl. Envir. Microbiol. 55: 2732-2734.

Servais, P., G. Billen \& M.-C. Hascoët, 1987. Determination of the biodegradable fraction of dissolved organic matter in waters. Wat. Res. 21: 445-450.

Sigg, L., M. Sturm \& D. Kistler, 1987. Vertical transport of heavy metals by settling particles in Lake Zürich. Limnol. Oceanogr. 32: $112-130$.

Stabel, H. H. \& M. Geiger, 1985. Phosphorus adsorption to riverine suspended matter, implications for the P-budget of lake Constance. Wat. Res. 19: 1347-1352.

Tilzer, M. M., 1988. Secchi disk - chlorophyll relationships in a lake with highly variable phytoplankton biomass. Hydrobiologia 162: $163-171$.

Vadstein, O., A. Jensen \& H. Reinertsen, 1988. Growth and phosphorus status of limnetic phytoplankton and bacteria. Limnol. Oceanogr. 31: 998-1009.

Vinçon-Leite, B., B. Tassin \& J.-M. Jaquet, 1995. Contribution of mathematical modeling to lake ecosystem understanding: Lake Bourget (Savoy, France). Hydrobiologia 300/301: 433-442.

Zumstein, J. \& J. Buffle, 1989. Circulation of pedogenic and aquagenic organic matter in an eutrophic lake. Wat. Res. 23: 229-239. 